\title{
Strategic orientation and the performance of SMEs in Indonesia: The mediating role of access to finance
}

\author{
Rinto Syahdan ${ }^{a^{*}}$, Yustiana Djaelani ${ }^{\mathrm{a}}$ and Suriana AR Mahdi ${ }^{\mathrm{a}}$
}

${ }^{a}$ Faculty of Economics and Business, Universitas Khairun Ternate, Indonesia

\begin{tabular}{l}
\hline C H R O N I C L E \\
\hline Article history: \\
Received: September 92019 \\
Received in revised format: Sep- \\
tember 122019 \\
Accepted: October 27, 2019 \\
Available online: \\
October 27, 2019 \\
\hline Keywords: \\
Market orientation (MO) \\
Entrepreneur orientation (EO) \\
Learning orientation (LO) \\
Technological orientation (TO) \\
Access to finance (AT) \\
Indonesia
\end{tabular}

\section{Introduction}

Performance is a relative concept/term used in many areas to describe how processes/actions realize their objectives. According to the theory of growth of the firm, performance is nothing more than an increase in the production of products which is the point where the average cost curve is at the minimal level for that particular product, given the optimal size of the firm. Similarly, we neem tp define firm performance as the quantified action of business activities, such as quantifying customer satisfaction. Therefore, firm performance is seen as the process of quantifying the efficiency and effectiveness of the firm actions. From an entrepreneurial point of view, SMEs' performance can be seen as how well the firm is managed and what the firm provides for its customers and owners. Simões et al. (2011) opine that SMEs performance is the amount of stakeholders' needs met by the firms and the extent to which firms utilize the resources to meet those needs. However, this study defines performance of SMEs in terms of the ability to survive, grow and contribute to the creation of employment and alleviate poverty. It is apparently essential to identify the strategic variables which may reflect the aforementioned management activities or processes, such as marketing, innovativeness, risk taking, technology and learning culture, where SMEs use and probably influence their performance. These firm's processes and managerial activities are referred to as strategic orientation that reflect the strategic directions executed to build proper behaviors for superior business performance. Noble et al. (2002) define strategic orientations as firm's beliefs, values and principles that the management uses to manage and utilize

\footnotetext{
* Corresponding author.

E-mail address: rintosyahdan@gmail.com (R. Syahdan) 
business resources. Similarly, strategic orientation is seen as the strategic activities performed by the firm to develop and improve firm activities for better performance. A firm's performance depends on the cultures and beliefs exhibited by firms when making decisions. Strategic orientation is a firm culture representing intangible resources that influences managerial activities and resource allocation. Strategic orientations are organizational decisions, in terms of actions, aimed at satisfying market needs and understanding actions of their competitors. This can be achieved by considering the environmental changes to provide better value to the market and strike a balance between the needs of the firm and consumer needs (Aragón-Sánchez \& Sánchez-Marín, 2005; Aktan \& Bulut, 2008).

Studies on Entrepreneur orientation (EO) argue that firms that take risks and are innovative and proactive, will experience better performance (Laukkanen et al., 2013; Rauch et al., 2009). Literature on Market orientation (MO) suggests that firms that are continually studying their customers' needs and competitors' actions will have more understanding in meeting their needs and will be in better position in combating their opponents (Eris \& Ozmen, 2012), However, due to the contextual nature of strategic orientations (Lumpkin \& Dess, 1996), the results of these studies are inconclusive and do not warrant generalization because they are contradictory. There are only few empirical studies incorporated on MO, EO, Technological orientation (TO), and Learning orientation (LO) together as the firm performance factors. In addition, limited empirical researches regarding the impact of financial access as mediator in the relation among firm performance and MO, EO, TO, and LO were found. The role of supportive business environment as a moderator in the SMEs performance is also unclear. Most SMEs performance-based studies were conducted for the developed economies. Only few researches are available on the firm performance and strategic orientations in Indonesia, particularly regarding the impact of MO, EO, TO and LO. Moreover, the studies that were conducted in past were based either on SME's or for big firms.

The present research gives insight about the association between SME's performance and MO, EO, TO, and LO in Indonesia. The study provides a clear understanding about the relationship among SME's performance in Indonesia and MO, EO, TO, and LO, and what mediating role of financial access plays in this relationship.

\section{Hypothesis Development}

Based on the objectives of this study and available evidence in literature, the following hypotheses were developed. Hypotheses (H1-H4) were developed based on the first objective of this study, which is concerned with the direct relationship between the independent variables and the dependent variable. The second objective provides grounds for hypotheses (H5-H8) which are concerned with the relationship between the independent variables and the mediator variable. Based on the third objective of this study, hypotheses (H9-H13) were developed which are concerned with the role of the mediating variable on the relationship between the independent variables and the dependent variable. Finally, hypotheses (H14-17) were developed based on the fourth objective of this study, which concerned with the role of the moderating variable on the relationship between the independent variables and the dependent variable.

Relationship between EO, MO, LO, TO and Firm Performance EO is one of the prominent constructs in management, strategy and entrepreneurship literature that affects firm performance. Early studies that investigated business performance have shown the importance of the EO construct on a firm's actions. Several scholars theorized a relationship between EO and firm performance (Lumpkin \& Dess, 1996). It has been reported by studies on firm performance that firms that are characterized by entrepreneurial behavior, such as risk taking, innovativeness and proactiveness, can achieve superior performance. For instance, Yang et al. (2008) argue that superior business performance can be achieved if the firm has sound entrepreneurial behavior. The influence of EO on firm performance has been confirmed by Awang et al. (2015) who report direct impact of combination of proactiveness, autonomy and innovativeness on firm performance. Similarly, EO improves firm performance as most performing firms exhibit some or all of EO activities. Additionally, it has been reported that business firms achieve superior performance through EO. Another study on EO and innovation performance reported a direct and indirect effect of EO on performance (Zainol et al., 2011). Entrepreneurial processes may lead to favorable outcomes on firm performance, EO enhances a firm's ability to take risks, be more innovative and act ahead of competitors (Al-Swidi \& Al-Hosam, 2012). Some studies have revealed that EO dimensions are significantly and positively related to business performance. The results confirm that the one dimensional EO construct will significantly affect business performance (Boohene et al., 2012). As EO gives firm a first move advantage, firms achieve higher performance (Fatoki, 2012). Therefore, a business with EO culture can act ahead of competitors by investing large amounts of resources in new market opportunities for high returns, which will lead to high performance. A number of empirical studies which tested the impact of MO on performance have reported that MO improves the firm performance. For example, Baker and Sinkula (2009) report a significant positive relationship between MO and firm performance. As MO represents an on-going response to customer needs and desires it facilitates the development of strategies focused on creating customer value, ultimately achieving competitive advantage (Dauda et al., 2010). Author emphasizes that considering customer needs and satisfaction as major priorities and constantly reassessing strengths and weaknesses relative to competitors, improves firm performance. Therefore, MO acts as a significant firm performance indicator, because marketoriented firms possess the ability of improving the financial performance and satisfying the customer needs through responding to their preferences, needs, and through tracking (Nikoomaram \& Ma'atoofi, 2011). Developing market-oriented firm behavior and culture, gathering information regarding customer preference and needs, market agents, and competitor capabilities may also act to be the superior performance indicators (Idar \& Mahmood, 2011). The effective and efficient ability of MO in creating the necessary behaviors towards better value for customers and assisting firms to achieve continuous superior 
performance. Scholar state that as a valuable resource, learning orientation (LO) allows the firm to exploit opportunities and neutralizes threats in a business environment. Thus, firms can understand the customers' needs better than their competitors, which will result in competitive advantage. According to Fan et al. (2008), when business firms are learning orientated, they will learn and develop a culture and behavior that will influence performance of the firm. They argue that there was a significant relationship between LO and firm performance, because it helps firms have a strong focus on the market, technology and environment.

Nikoomaram and Ma'atoofi (2011) found that business firms that place a high value on learning have significantly higher levels of performance. Hence, LO promotes a successful development of products that will satisfy market needs. Business firms that are characterized with a high learning culture have been found to be able to challenge old assumptions about the market and reorganize their firms to achieve competitive advantage. It can be concluded that due to the basic principle that firms learn from experience, learning can lead to improved economic performance by reducing the cost of production (Mahmoud \& Yusif, 2012). Technological firms may have the will and ability to use them for learning better technologies and achieving superior performance. Such technological firms adopted innovation as a strategic priority, which resulted in adaptability, gaining technical skills, proactivity and creativity in developing services and products. Thus, in order to achieve product differentiation and innovative product designs, Technological orientation (TO) provides a major solution, which in turn improves the firms' performance Qin et al. (2010) suggested that a firm performance usually is enhanced by developing adaptive capability, therefore, firms are required to increase their technological capacity. The technological firms support greater commitment in acquiring new technologies, engagement with the R\&D, and latest technological implementation leading to enhanced performance of the firm (Mu \& Di Benedetto, 2011). Spanjol et al. (2011) have argued that with such applications, technological firms possess competitive advantage with regards to technology, and extend differentiated goods leading to enhanced firm performance. Hakala and Kohtamäki (2010) also reported that firms' overall and product performance were found to be positively associated with TO. Thus, the following hypotheses are formulated:

$\mathbf{H}_{1}$ : EO is positively related to performance of SMEs in Indonesia.

H2: MO is positively related to performance of SMEs in Indonesia.

$\mathbf{H}_{3}$ : LO is positively related to performance of SMEs in Indonesia.

$\mathbf{H}_{4}$ : TO is positively related to performance of SMEs in Indonesia

\subsection{Role of Access to Finance}

A firm's financial capital is a commonest and is comparatively easy resource to convert into other resources. Thus, for the performance of small businesses, access to capital is somehow essential (Wiklund \& Shepherd, 2005). In Indonesia, access to finance is a critical issue and a it is main reason for the low performance of SME's. Thus, obtaining financial resources could be helpful in improving the performance of these SMEs'. Moreover, determining a significant association among performance and access to finance is important. Several empirical researches have indicated that the superior performance of a firm can be achieved through acquiring financial capital. According to scholar, ensuring accessibility to finance enhances firms' growth and development and in turn, influences overall economic performance positively. Wiklund and Shepherd (2005) reported that for small businesses to achieve and sustain competitive advantage, they need good access to financial resources. The study confirmed that access to financial capital can improve firm performance. In this way, SMEs that combine together these imperative orientations are expected to deliver more and generate both internal and external financing. Taken together, this study hypothesizes that:

H5: There is a positive relationship between EO and SMEs' access to finance in Indonesia.

H6: There is a positive relationship between MO and SMEs' access to finance in Indonesia.

H7: There is a positive relationship between LO and SMEs' access to finance in Indonesia.

H8: There is a positive relationship between TO and SMEs' access to finance in Indonesia.

Kyophilavong (2011) supports that access to finance positively influences SMEs' performance. Moreover, Demir and Caglayan (2012) affirm that firm performance is positively influenced by access to finance. Similarly, it is concluded that there is a positive and significant link between a firm's financing and business performance. Based on these issues, it is expected that access to finance will have significant positive influence on performance of SMEs in Indonesia. Therefore, this study posits that:

H9: There is a positive relationship between access to finance and performance of SMEs in Indonesia.

Lastly, since financial resources enhance the performance of a firm therefore, it is the firms' strategies which determine its performance. Mohammed and Obeleagu-Nzelibe (2014) suggested that apparently, high entrepreneurial skills lead to better 
access to financial resources. Similarly, market-oriented firms positively influence the profitability of a firm. Briefly, such firms are expected to have high income through learning from their surroundings.

Technological superiority is a strategy which is used by firms to enhance fund receiving ability, therefore these firms possess the ability of developing superior products which may compete with other market products. On the basis of such proposition, it is assumed that SMEs performance and MO, EO, TO and LO are positively related to each other through access to finance mechanism. This is an important contribution of this study, since it has provided more distinctive explanation about the influence of strategic orientations on the firm performance. Several researchers investigated and reported that firm performance have been influenced by MO, EO, TO and LO, however limited empirical literature is available on the access to finance mechanism affecting the firm performance. Thus, necessary information can be provided by the access to finance that how MO, EO, TO, and LO improves the performance of a firm. Putting differently, it is postulated that:

$\mathbf{H}_{10}$ : Access to finance mediates the positive relationship between EO and performance of SMEs in Indonesia.

H11: Access to finance mediates the positive relationship between MO and performance of SMEs in Indonesia.

H12: Access to finance mediates the positive relationship between LO and performance of SMEs in Indonesia.

$\mathbf{H}_{13}$ : Access to finance mediates the positive relationship between TO and performance of SMEs in Indonesia.

Based on the literature reviewed and suggestions by several studies, this study has developed a framework to investigate the mediating role of access to finance and the moderating role of business environment on the relationship between EO, MO, LO, TO and performance of SMEs in Indonesia. The research framework has four independent variables that represent the firm's valuable resources, namely EO, MO, LO and TO. Firm performance is the dependent variable, while access to finance is the mediating variable and business environment is the moderating variable EO as suggested by the literature is one of widely used strategic orientation variables. It has been shown in several studies that EO is a very important firm resource as postulated by the theory. Several studies have used this important VRIN resource to investigate the performance of the business firms. Therefore, this study adapts EO as an independent variable that indicates the extent to which SMEs are entrepreneurial in terms of proactiveness, risk taking and innovativeness. This is in line with the suggestion that future studies that investigate firm performance should include EO (Didonet, Simmons, Díaz-Villavicencio, \& Palmer, 2012).

Several studies have shown the VRIN nature of MO in creating necessary behaviors to achieve competitive advantage for superior performance (Mahmoud \& Yusif, 2012). A number of studies have suggested further investigation on the effect of MO on performance. For instance, Didonet et al. (2012) suggest an inclusion of MO in firm performance studies. Therefore, this study adapted MO as the SMEs' valuable resource that focuses on understanding and meeting customers' needs and desires through the activities of customer orientation, competitor orientation and inter-functional coordination. The study shows the capability of LO in predicting firm performance even with the rapid changes in the environment. Consequently, several studies recognize the power of LO in predicting firm performance; this has made LO a more valuable firm resource in several studies. Consequently, this study adapts LO as an independent variable that indicates the influence of SMEs values in creating knowledge and using knowledge to enhance performance through the activities of commitment to learning, openmindedness and shared vision. The last independent variable in this study, TO, is also found to be an important factor that gives a firm competitive advantage. This is in line with view of Cho and Pucik (2005) that technology orientation is a VRIN resource that can determine the performance of business firms. Therefore, based on the previous studies, this study adapts TO as an independent variable that indicates the ability of the SMEs in terms of using new technology and innovation to produce, improve or develop products and services (Spanjol et al., 2011). Finally, the essential idea is that strategic orientations are complementary; hence, the combination of these resources will provide firms with competitive advantage. According to Demir and Caglayan (2012), firm performance is positively related to having access to financial resources. In a similar finding, it has been indicated that an increased access to finance positively influences firm productivity and performance. Additionally, Wiklund and Shepherd (2005) state that access to finance is an important factor in determining small businesses' performance. Similarly, author found that access to finance enhances performance. Therefore, this study adopt access to finance as the mediating variable to indicate how SMEs can achieve competitive advantage if they have access finance (internal and external) with minimal or absence of financial and non-financial barriers. The contingency theory postulates that for a firm to achieve competitive advantage, it must consider its internal and external environments. Therefore, business environment is perceived as a contingent variable that can have impact on the strategic orientations and firm performance relationship. Besides, strategic orientation studies appear to be deficient without taking the environmental contingencies into consideration. Correspondingly, that strategic orientations are portrayed by environment and social contrasts. Therefore, business environment is adapted as a moderating variable that indicates the extent to which a business environment can provide resources, assistance and support needed by SMEs operating within an environment for sustainability and growth of the enterprise. This is in line with suggestions made for future research.

\section{Methodology}

Data analysis is a statistical tool for analyzing data, and hypotheses testing as well as for revising theories. The present study employed descriptive and inferential statistics for the data analysis. In addition, the Partial Least Square Structural Equation Modeling (PLS-SEM) was also adopted. After collecting first hand data through questionnaires, it was then coded into the 
SPSS for statistical analysis. Firstly, it went through the screening process to omit any errors. Afterwards, for each variable a frequency test was performed to identify any missing values and make corrections by adding respective mean values. Secondly, descriptive statistics were then obtained for describing and having a demographic comparison. Finally, PLS-SEM, a second order SEM technique was employed. Hair et al. (2011) suggested that the structural equation modeling plays an important role for observing the cause-and-effect association among the latent constructs. PLS-SEM is generally a statistical path modeling method to develop complex multivariate models encompassing relation among the latent and observed variables (Vinzi et al., 2010). In addition to this, PLS-SEM approach is a superior, flexible, and a strong statistical model tool for predicting theories and testing hypotheses. However, Afthanorhan (2013) strongly recommended PLS-SEM path modeling for valid and reliable confirmatory factor analysis (CFA).

\section{Results}

As a superior model having second generation, the PLS-SEM performs better estimation and covariance regression models to examine the moderating and mediating variables. On the basis of discussion and arguments given to choose PLS-SEM as a suitable statistical technique, the present study then employed a PLS-SEM because of its research model complexity. In view of other researchers, it is an appropriate method having several exogenous variables which explained a few endogenous latent variables (Hair et al., 2011). Thus, PLS-SEM can particularly be used in the area of social sciences, strategic management and marketing as it is a multivariate analysis method. Moreover, PLS-SEM do not pose any restrictions on the interaction technique, as compared with other covariance techniques. Thus, it is a feasible replacement to analyze the moderation effect. Lowry and Gaskin (2014) argued that complex model can be estimated through PLS-SEM involving chain of effects, i.e. mediation and complex relations. Therefore, SmartPLS v.3.0 is used in this study for estimating the convergent validity, discriminant validity, and reliability for the outer model and the coefficient of determination, path coefficients significance, predictive relevance, and the effect size for the inner model.

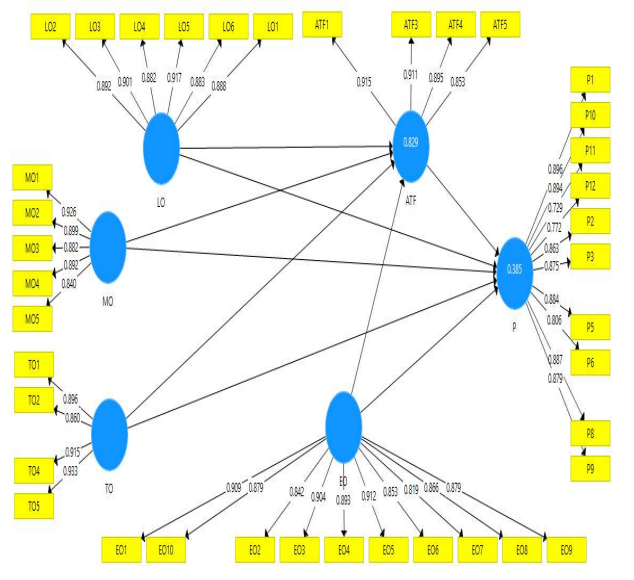

Fig. 1. Measurement model

Table 1

Reliability

\begin{tabular}{ccccc}
\hline & Cronbach's Alpha & rho A & Composite Reliability & Average Variance Extracted (AVE) \\
\hline ATF & 0.916 & 0.922 & 0.941 & 0.799 \\
EO & 0.966 & 0.967 & 0.971 & 0.767 \\
LO & 0.950 & 0.952 & 0.960 & 0.799 \\
MO & 0.933 & 0.934 & 0.949 & 0.789 \\
P & 0.957 & 0.961 & 0.963 & 0.723 \\
TO & 0.923 & 0.927 & 0.945 & 0.813 \\
\hline
\end{tabular}

During PLS-SEM estimation, the first step is to estimate the measurement model, also known as the outer-model. It involves component measurement, indicating how well the item of the indicators load theoretically and correspond to their respective constructs. In addition, outer-model estimation also confirms whether the respective constructs are measured by the survey items, as they were assumed to measure, thus ensuring their validity and reliability. Reliability and validity, are the important criteria used for outer-model estimation in PLS-SEM analysis(Hair Jr et al., 2013). Validity and reliability of the measures also determine the association of variables in the inner model. Furthermore, the outer-model's compatibility can be observed by assessing 1) individual reliabilities of the items, such as internal consistency reliability and reliability of indicator, using a measure of composite reliability; 2) discriminant validity of the model using outer loadings and a Fornell and Larcker (1981) criterion; and 3) convergent validity for the individual measures of the construct through AVE. Starting with internal consistency, which determines the consistency among the same test items, i.e. whether items of the constructs show similar scores. Thus, internal consistency for this study was measured through composite reliability. The value for CR lies within 0 and 1 , 
having 0.60 as a threshold value (Henseler et al., 2009), however, it must be equal to or above 0.70 to be at desirable level. If the value for CR lies within 0.6 and 0.7 , then it represents average internal consistency, while if CR lies between 0.7 and 0.9 it represents internal consistency of adequate level. Another criterion is convergent validity, which is defined as the level to which two measures from a same construct which should be related theoretically are in fact related with each other (Henseler et al., 2009). Thus it shows the level of correlation between the measures of the same construct. For this purpose, average value extracted (AVE) is employed, having 0.50 as a threshold value or the adequate convergent validity. Therefore, latent constructs indicate an adequate level of convergent validity and explain indicator's half variance (Hair Jr et al., 2013). Afterwards, discriminant validity was observed, which shows whether measurements that are assumed to be unrelated are actually unrelated from each other (Hair Jr et al., 2013). Fornell and Larcker (1981) criterion is a standard approach for confirming discriminant validity for the study (Hair Jr et al., 2013). Besides, Fornell and Larcker (1981) criterion, cross-loading method can also be used for checking discriminant validity, since it is more radical and have more constructs.

Table 2

Discriminant Validity

\begin{tabular}{|c|c|c|c|c|c|c|}
\hline & ATF & $\mathrm{EO}$ & LO & $\mathrm{MO}$ & $\mathrm{P}$ & TO \\
\hline ATF & 0.934 & & & & & \\
\hline EO & 0.716 & 0.976 & & & & \\
\hline LO & 0.670 & 0.921 & 0.894 & & & \\
\hline $\mathrm{MO}$ & 0.877 & 0.686 & 0.690 & 0.988 & & \\
\hline $\mathrm{P}$ & 0.533 & 0.585 & 0.520 & 0.525 & 0.850 & \\
\hline TO & 0.893 & 0.712 & 0.674 & 0.921 & 0.553 & 0.901 \\
\hline
\end{tabular}

Lastly, in order to examine contribution of indicator in the assigned construct, outer factor loadings were obtained. The value for outer loadings must exhibit 0.50 or above value. It has been suggested by Hair Jr et al. (2013) that if the outer loadings exhibit value which is below 0.70 and value above 0.40 , than it must be carefully observed and deleted in case it is higher than the AVE and CR values.

Table 3

Outer Loadings

\begin{tabular}{|c|c|c|c|c|c|c|}
\hline & ATF & EO & LO & $\mathrm{MO}$ & $\mathrm{P}$ & TO \\
\hline ATF1 & 0.915 & & & & & \\
\hline ATF3 & 0.911 & & & & & \\
\hline ATF4 & 0.895 & & & & & \\
\hline ATF5 & 0.853 & & & & & \\
\hline EO1 & & 0.909 & & & & \\
\hline EO10 & & 0.879 & & & & \\
\hline $\mathrm{EO} 2$ & & 0.842 & & & & \\
\hline EO3 & & 0.904 & & & & \\
\hline EO4 & & 0.893 & & & & \\
\hline EO5 & & 0.912 & & & & \\
\hline EO6 & & 0.853 & & & & \\
\hline EO7 & & 0.819 & & & & \\
\hline EO8 & & 0.866 & & & & \\
\hline EO9 & & 0.879 & & & & \\
\hline $\mathrm{LO} 2$ & & & 0.892 & & & \\
\hline LO3 & & & 0.901 & & & \\
\hline LO4 & & & 0.882 & & & \\
\hline LO5 & & & 0.917 & & & \\
\hline LO6 & & & 0.883 & & & \\
\hline MO1 & & & & 0.926 & & \\
\hline MO2 & & & & 0.899 & & \\
\hline MO3 & & & & 0.882 & & \\
\hline MO4 & & & & 0.892 & & \\
\hline MO5 & & & & 0.840 & & \\
\hline P1 & & & & & 0.896 & \\
\hline P10 & & & & & 0.894 & \\
\hline P11 & & & & & 0.729 & \\
\hline P12 & & & & & 0.772 & \\
\hline P2 & & & & & 0.863 & \\
\hline P3 & & & & & 0.875 & \\
\hline P5 & & & & & 0.884 & \\
\hline P6 & & & & & 0.806 & \\
\hline P8 & & & & & 0.887 & \\
\hline P9 & & & & & 0.879 & \\
\hline TO1 & & & & & & 0.896 \\
\hline TO2 & & & & & & 0.860 \\
\hline TO4 & & & & & & 0.915 \\
\hline TO5 & & & & & & 0.933 \\
\hline LO1 & & & 0.888 & & & \\
\hline
\end{tabular}


The next step after checking collinearity is the structural model estimation. Estimating structural model involves following steps i.e. checking predictive relevance, coefficient of determination, significance of path coefficients, and coefficient of determination.

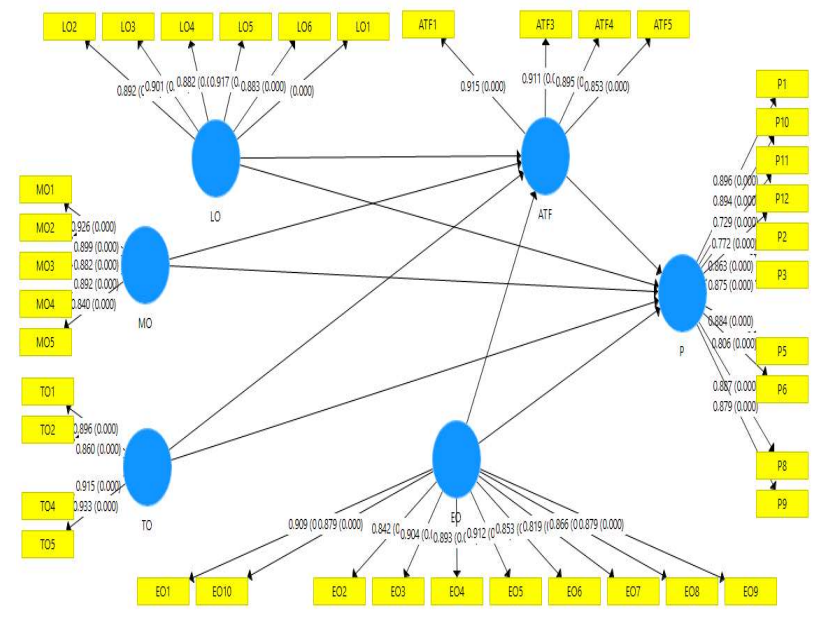

Fig. 2. Structural Model

Afterwards, a bootstrapping procedure has been used which examines the path model for the direct association between dependent and the independent variables, without observing the role of a mediator. The path coefficients obtained through PLSSEM algorithm and t-values obtained from the bootstrapping procedure are the path models (Hair Jr et al., 2013). The path models with mediator variables were estimated in the second step. The major emphasis is to assess that whether relationship of mediator among the dependent as well as independent variables is significant. It is a necessary but not a sufficient condition for determining the effect of mediator. Lastly, to determine indirect effect's significance, the product of path coefficients for two indicators was divided by the standard error of this product.

Table 4

Direct relationships

\begin{tabular}{cccccc}
\hline & Original Sample $(\mathrm{O})$ & Sample Mean $(\mathrm{M})$ & $\begin{array}{c}\text { Standard Deviation } \\
(\text { STDEV })\end{array}$ & T Statistics $(|\mathrm{O} / \mathrm{STDEV}|)$ & P Values \\
\hline $\mathrm{ATF} \rightarrow \mathrm{P}$ & 0.023 & 0.031 & 0.140 & 3.166 & 0.000 \\
$\mathrm{EO} \rightarrow$ ATF & 0.248 & 0.250 & 0.097 & 2.550 & 0.011 \\
$\mathrm{EO} \rightarrow \mathrm{P}$ & 0.549 & 0.549 & 0.170 & 3.226 & 0.001 \\
$\mathrm{LO} \rightarrow$ ATF & -0.122 & -0.116 & 0.097 & 3.261 & 0.000 \\
$\mathrm{LO} \rightarrow \mathrm{P}$ & -0.185 & -0.184 & 0.169 & 3.094 & 0.000 \\
$\mathrm{MO} \rightarrow$ ATF & 0.364 & 0.362 & 0.085 & 3.295 & 0.000 \\
$\mathrm{MO} \rightarrow \mathrm{P}$ & 0.084 & 0.075 & 0.167 & 3.505 & 0.000 \\
$\mathrm{TO} \rightarrow$ ATF & 0.464 & 0.458 & 0.089 & 5.222 & 0.000 \\
$\mathrm{TO} \rightarrow \mathrm{P}$ & 0.208 & 0.221 & 0.171 & 3.217 & 0.000 \\
\hline
\end{tabular}

For the testing of hypotheses (H1-H13) proposed in this study, the structural model has been systematically analyzed. The inner model analyzed the direct association among the independent and the dependent variables. PLS-Algorithm was used to determine the size of path coefficients while PLS-SEM bootstrapping procedure was adopted to assess the significance using SmartPLS 3.0. Following (Hair et al., 2011; Hair Jr et al., 2013), 5000 bootstrapping samples were employed and the actual number of cases is taken as the number of cases. The first model determines the nature of association among independent and dependent variables, which encompasses H1-H4 hypotheses. On the other hand, a mediating variable has been introduced in the second model and the model then analyzed the relation among this mediating variable and the independent variables. Afterwards, model also observed the relation among dependent variable and the mediator.

Table 5

Mediation results

\begin{tabular}{cccccc}
\hline & Original Sample $(\mathrm{O})$ & Sample Mean $(\mathrm{M})$ & Standard Deviation $(\mathrm{STDEV})$ & $\mathrm{T}$ Statistics $(|\mathrm{O} / \mathrm{STDEV}|)$ & $\mathrm{P}$ Values \\
\hline $\mathrm{EO} \rightarrow \mathrm{ATF} \rightarrow \mathrm{P}$ & 0.006 & 0.003 & 0.036 & 4.159 & 0.000 \\
$\mathrm{LO} \rightarrow \mathrm{ATF} \rightarrow \mathrm{P}$ & -0.003 & 0.000 & 0.021 & 3.138 & 0.000 \\
$\mathrm{MO} \rightarrow \mathrm{ATF} \rightarrow \mathrm{P}$ & 0.008 & 0.010 & 0.051 & 3.166 & 0.000 \\
$\mathrm{TO} \rightarrow \mathrm{ATF} \rightarrow \mathrm{P}$ & 0.011 & 0.018 & 0.068 & 3.158 & 0.000 \\
\hline
\end{tabular}


The Structural model also considers the predictive relevance ability of the model through Stone-Geisser criterion. This criteria expects inner-model to give predictive evidence regarding the latent constructs of the endogenous variables (Henseler et al., 2009). Thus, Stone-Geisser's predictive relevance criterion has been used in this study, using blindfolding method, which provides a cross-validated measure for the latent construct.

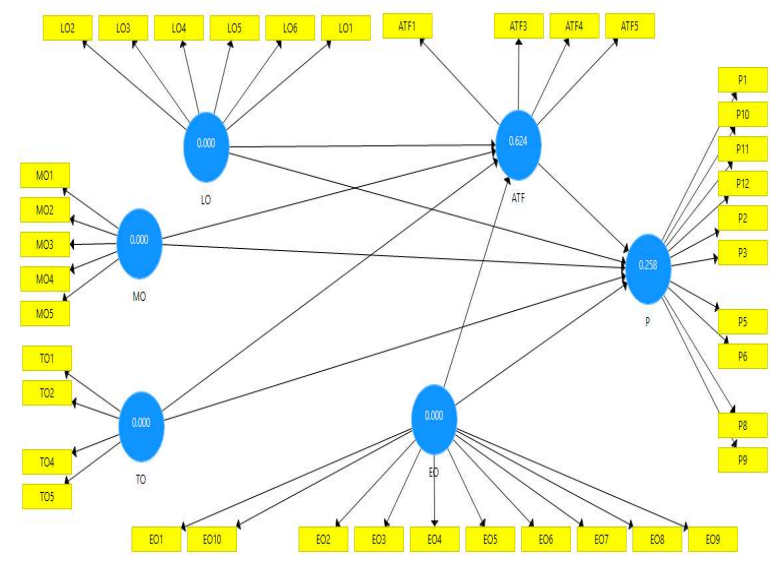

Fig. 3. Blind Folding

\section{Table 5}

Relevance Ability

\begin{tabular}{cc}
\hline & $\mathrm{Q}^{2}(=1-\mathrm{SSE} / \mathrm{SSO})$ \\
\hline ITS & 0.631 \\
\hline
\end{tabular}

\section{Conclusion}

Relationship between EO, MO, LO, TO and Firm Performance EO is one of the prominent constructs in management, strategy and entrepreneurship literature that affects firm performance. Early studies that investigated business performance have shown the importance of the EO construct on a firm's actions. Several scholars theorized a relationship between EO and firm performance. It has been reported by studies on firm performance that firms that are characterized by entrepreneurial behavior, such as risk taking, innovativeness and proactiveness, can achieve superior performance. For instance, the study is in line with Yang et al. (2008) argues that superior business performance can be achieved if the firm has sound entrepreneurial behavior. The influence of EO on firm performance has been confirmed by Awang, Afthanorhan, and Asri (2015) who report direct impact of combination of proactiveness, autonomy and innovativeness on firm performance. Similarly, EO improves firm performance as most performing firms exhibit some or all of EO activities. Additionally, it has been reported that business firms achieve superior performance through EO. Another study on EO and innovation performance reported a direct and indirect effect of EO on performance. Therefore, MO acts as a significant firm performance indicator, because market-oriented firms possess the ability of improving the financial performance and satisfying the customer needs through responding to their preferences, needs, and through tracking. Present research gives insight about the association between market orientation, entrepreneur orientation, learning orientation, technological orientation and access to finance, and SME's performance in Indonesia. The study provides a clear understanding about the relation among SME's performance in Indonesia and market orientation, entrepreneur orientation, learning orientation, technological orientation, and what mediating role financial access play in this relationship. The study broached that it is apparently essential to identify the strategic variables which may reflect the aforementioned management activities or processes, such as marketing, innovativeness, risk taking, technology and learning culture, which SMEs use and that probably influence their performance. The study is among the pioneering studies on the issues related to the market orientation, entrepreneur orientation, learning orientation, technological orientation, and access to finance in Indonesia. So, current study has used SEM-PLS as statistical tool to answer the research questions raised in this study and research objectives envisaged in the current study. The findings of the current study have provided support to with the hypothesized results. The study has argued that the to deal with the current external opportunities and menaces, new knowledge and skills for improving their existing and future performances must be provided for the organizations This study will be helpful for policymakers and researchers in examining the link between market orientation, entrepreneur orientation, learning orientation, technological orientation, and access to finance in Indonesia performance of SMEs in Indonesia. Technological firms may have the will and ability to use them for learning better technologies and achieving superior performance. Such technological firms adopted innovation as a strategic priority, which resulted in adaptability, gaining technical skills, proactivity and creativity in developing services and products. Thus, in order to achieve product differentiation and innovative product designs, there is a need to provide a major solution, which in turn improves the firms' performance. 


\section{References}

Afthanorhan, W. (2013). A comparison of partial least square structural equation modeling (PLS-SEM) and covariance based structural equation modeling (CB-SEM) for confirmatory factor analysis. International Journal of Engineering Science and Innovative Technology, 2(5), 198-205.

Aktan, B., \& Bulut, C. (2008). Financial performance impacts of corporate entrepreneurship in emerging markets: A case of Turkey. European Journal of Economics, Finance and Administrative Sciences, 12(8), 1530-2275.

Al-Swidi, A. K., \& Al-Hosam, A. (2012). The effect of entrepreneurial orientation on the organizational performance: A study on the Islamic banks in Yemen using the partial least squares approach. Oman Chapter of Arabian Journal of Business and Management Review, 34(970), 1-12.

Aragón-Sánchez, A., \& Sánchez-Marín, G. (2005). Strategic orientation, management characteristics, and performance: A study of Spanish SMEs. Journal of Small Business Management, 43(3), 287-308.

Awang, Z., Afthanorhan, A., \& Asri, M. (2015). Parametric and non parametric approach in structural equation modeling (SEM): The application of bootstrapping. Modern Applied Science, 9(9), 58.

Baker, W. E., \& Sinkula, J. M. (2009). The complementary effects of market orientation and entrepreneurial orientation on profitability in small businesses. Journal of Small Business Management, 47(4), 443-464.

Boohene, R., Marfo-Yiadom, E., \& Yeboah, M. (2012). An empirical analysis of the effect of entrepreneurial orientation on firm performance of auto artisans in the Cape Coast Metropolis. Developing Country Studies, 2(9), 77-86.

Cho, H. J., \& Pucik, V. (2005). Relationship between innovativeness, quality, growth, profitability, and market value. Strategic management journal, 26(6), 555-575.

Dauda, Y. A., Akingbade, W. A., \& Akinlabi, H. B. (2010). Strategic management practice and corporate performance of selected small business enterprises in Lagos metropolis. International Journal of Business and Management, 5(11), 97.

Demir, F., \& Caglayan, M. (2012). Firm productivity, exchange rate movements, sources of finance and export orientation (No. 37397): Munich.

Didonet, S., Simmons, G., Díaz-Villavicencio, G., \& Palmer, M. (2012). The relationship between small business market orientation and environmental uncertainty. Marketing Intelligence \& Planning, 30(7), 757-779.

Eris, E. D., \& Ozmen, O. N. T. (2012). The effect of market orientation, learning orientation and innovativeness on firm performance: A research from Turkish logistics sector. International Journal of Economic Sciences \& Applied Research, $5(1)$.

Fan, R.-E., Chang, K.-W., Hsieh, C.-J., Wang, X.-R., \& Lin, C.-J. (2008). LIBLINEAR: A library for large linear classification. Journal of machine learning research, 9(Aug), 1871-1874.

Fatoki, O. (2012). An investigation into the financial management practices of new micro-enterprises in South Africa. Journal of social sciences, 33(2), 179-188.

Fornell, C., \& Larcker, D. F. (1981). Structural equation models with unobservable variables and measurement error: Algebra and statistics: SAGE Publications Sage CA: Los Angeles, CA.

Hair, J. F., Ringle, C. M., \& Sarstedt, M. (2011). PLS-SEM: Indeed a silver bullet. Journal of Marketing theory and Practice, 19(2), 139-152.

Hair Jr, B., Claudia, J. F., Pieper, T. M., \& Baldauf, A. (2013). Exploring the effect of distinct family firm reputation on consumers' preferences. Journal of Family Business Strategy, 4(1), 3-11.

Hakala, H., \& Kohtamäki, M. (2010). The interplay between orientations: Entrepreneurial, technology and customer orientations in software companies. Journal of Enterprising Culture, 18(03), 265-290.

Henseler, J., Ringle, C. M., \& Sinkovics, R. R. (2009). The use of partial least squares path modeling in international marketing New challenges to international marketing (pp. 277-319): Emerald Group Publishing Limited.

Idar, R., \& Mahmood, R. (2011). Marketing Orientation As Mediator To Entrepreneurial Orientation and Performance Relationship: Evidence From Falaysian SMES.". Rising to the Global Challenge: Entrepreneurship and SMEs development in Asia.

Kyophilavong, P. (2011). SMEs access to finance: Evidence from Laos. Small and Medium Enterprises (SMEs) Access to Finance in Selected East Asian Economies, 117-150.

Laukkanen, T., Nagy, G., Hirvonen, S., Reijonen, H., \& Pasanen, M. (2013). The effect of strategic orientations on business performance in SMEs: A multigroup analysis comparing Hungary and Finland. International Marketing Review, 30(6), 510-535.

Lowry, P. B., \& Gaskin, J. (2014). Partial least squares (PLS) structural equation modeling (SEM) for building and testing behavioral causal theory: When to choose it and how to use it. IEEE transactions on professional communication, 57(2), 123-146.

Lumpkin, G. T., \& Dess, G. G. (1996). Clarifying the entrepreneurial orientation construct and linking it to performance. Academy of management review, 21(1), 135-172.

Mahmoud, M., \& Yusif, B. (2012). Market orientation, learning orientation, and the performance of nonprofit organisations (NPOs). International Journal of Productivity and Performance Management, 61(6), 624-652.

Mohammed, U. D., \& Obeleagu-Nzelibe, C. G. (2014). Entrepreneurial skills and profitability of Small and Medium Enterprises (SMEs): Resource acquisition strategies for new ventures in Indonesia. Paper presented at the Proceedings of 25th International Business Research Conference. 
Mu, J., \& Di Benedetto, C. A. (2011). Strategic orientations and new product commercialization: mediator, moderator, and interplay. R\&D Management, 41(4), 337-359.

Nikoomaram, H., \& Ma'atoofi, A. R. (2011). The effect of learning orientation on market orientation and performance in small-sized firms: Evidence from Iran. European Journal of Social Sciences, 18(4), 632-642.

Noble, C. H., Sinha, R. K., \& Kumar, A. (2002). Market orientation and alternative strategic orientations: a longitudinal assessment of performance implications. Journal of marketing, 66(4), 25-39.

Qin, J., Li, R., Raes, J., Arumugam, M., Burgdorf, K. S., Manichanh, C., . . Yamada, T. (2010). A human gut microbial gene catalogue established by metagenomic sequencing. Nature, 464(7285), 59.

Rauch, A., Wiklund, J., Lumpkin, G. T., \& Frese, M. (2009). Entrepreneurial orientation and business performance: An assessment of past research and suggestions for the future. Entrepreneurship Theory and practice, 33(3), $761-787$.

Simões, J. M., Gomes, C. F., \& Yasin, M. M. (2011). A literature review of maintenance performance measurement: A conceptual framework and directions for future research. Journal of Quality in Maintenance Engineering, 17(2), $116-137$.

Spanjol, J., Qualls, W. J., \& Rosa, J. A. (2011). How many and what kind? The role of strategic orientation in new product ideation. Journal of Product Innovation Management, 28(2), 236-250.

Vinzi, V. E., Chin, W. W., Henseler, J., \& Wang, H. (2010). Handbook of partial least squares: Springer.

Wiklund, J., \& Shepherd, D. (2005). Entrepreneurial orientation and small business performance: a configurational approach. Journal of business venturing, 20(1), 71-91.

Yang, J.-Y., Zong, C. S., Xia, W., Yamaguchi, H., Ding, Q., Xie, X., . . Huang, W.-C. (2008). ERK promotes tumorigenesis by inhibiting FOXO3a via MDM2-mediated degradation. Nature cell biology, 10(2), 138.

Zainol, F. A., Daud, W., \& Norhayate, W. (2011). Indigenous ("Bumiputera") Malay entrepreneurs in Malaysia: Government supports, entrepreneurial orientation and firms performances. International Business and Management, 2(1), 86-99.

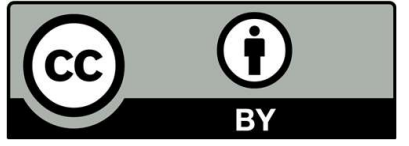

(C) 2020 by the authors; licensee Growing Science, Canada. This is an open access article distributed under the terms and conditions of the Creative Commons Attribution (CC-BY) license (http://creativecommons.org/licenses/by/4.0/). 